\title{
Evaluation of Teaching Methods in the Individual and Team
}

\author{
Junardi Harahap \\ Department of Anthropology \\ Faculty of Social Science and Political Science \\ Universitas Padjadjaran, Bandung, Indonesia \\ (Email: junardiharahap@gmail.com)
}

\begin{abstract}
Education and teaching have long process and need evaluation in it. With the evaluation, the learning process will be well-implemented, and also, the quality of learning in teaching will work well too. Creative ideas in learning will also appear better and the successfulness in teaching will also be achieved. The question in this study is about the quality of teaching method, comparing the process of teaching based on team teaching and individual teaching to find out the better method. The method in this study is a qualitative method, based on experience while doing individual teaching the team teaching method. The results showed that both methods of team and individual teaching have weaknesses and advantages. One of the merits in individual teaching is the control of the teaching only lies on one person, while for team teaching, there are strict controls. In team teaching, sometimes, the process of deepening and getting closer with students are underdeveloped, this is in contrast to the method of individual teaching methods.
\end{abstract}

Keywords-teaching, team teaching, individualized, and evaluation of teaching

\section{INTRODUCTION}

Teaching is important and urgent because good teaching will produce good results. Good teaching requires a lot of knowledge and aspects to obtain the necessary objectives. Good teaching requires diligence and discipline to get good grades. The values given must also be controlled to obtain a good result. Values and knowledge is something that cannot be separated and must be understood properly. Being lecturer needs good values to obtain maximum results and led to the desired achievement.

Absolute knowledge is necessary to accomplish what you want. Objectives to be achieved by a lecturer are to make the students to be smart and good. Being smart and intelligent is the desire to be desired by a teacher who is able to bring the students to be successful people in the future. To make the students smart is not an easy case, because it requires hard work from all elements, both lecturers and students. A student is required to be able to study seriously. Meanwhile, the lecturer is required to perform a variety of devices that can lead students to better and positive direction. Lecturer in performing their duties must be able to do things that are positive and good. Lecturers are people who carry a lot of students to live properly. Lecturers are people who make a difference in students' future. Lecturers always do a lot of changes and students are become better and respectable.

\section{METHOD}

The method used in this research is qualitative, this is the methods that is done by observation through teaching process. [1] The method is used through teaching experience during the teaching-learning activity in the classroom. Thing that is also observed is interaction between students with lecturers during team and individual teaching method that are applied. The focus this study is the result of teaching experience and teaching the instrument in the focus of research. The instrument of this study are students and lecturers who serve as informants during the teaching process in the classroom. The results of this research instrument used as a source of data analysis from this study, which produce data analysis as described in the data analysis.

\section{LITERATURE REVIEW}

In their study stated that the goodness in developing teaching by wearing the team is able to make a good model in teaching in a team so as to achieve the desired teaching. [2] Argues with the use of their teaching the people in the team will achieve a working partner in the team so it can happen a heated discussion achieve the objectives to be achieved within the teaching team. [3] Acknowledges in the teaching faculty who conduct therein team will be able to do a good interaction with fellow faculty to improve teaching that this is actually desired interaction will bring to the quality of teaching in running well. [4]

Provides guidance on outlook concerns regarding a teaching that leads to their feedback in the teaching and it is an advantage gained from a teaching-based to a team than the teaching is done individually. [5] Provides an overview provide direction on more effective in deciding something so that in teaching activities can be run well. [6] Claims in a teaching is done in the team compared to that done by yourself is that the team will be going innovation in teaching compared to do with themselves. [7] Provides a view of matters relating to the evaluation in the study at the University is an ongoing process, which brings to their colleagues in the teaching provide more direction on the inside team can all contribute. [8]

A planner in the learning operation is necessary, where the teachers to plan instruction that occurs in the quality of learning that can run well and smoothly.[9] Mentioned that in evaluation in learning is very useful for getting results 
and good performances in teaching and evaluation conducted properly and smoothly in the teaching. [10]

\section{RESULTS AND DISCUSSION}

The good professor is a lecturer who is able to make students become good people and have the ability to perform tasks well. They always lead the students to be good people and always do a lot of things for students to bring the desired-changes. For that reason, lecturers and students should be able to cooperate properly. Good lecturers are people who are able to bring students into people who are disciplined and do a lot of things in his life someday. Good lecturers are lecturers who always taught me many things in society that leads to things that are desired by him.

To achieve what is desired by a student to have a good and successful life, it needs tenacity and great desire from both students and lecturers. And it should be done properly and correctly. As discussed with other lecturers who have a desire to accomplish the duty properly, the process need helps from many people who move around and do a lot of good things to him.

Lecturers, as people who have experience in various lectures as those who carry the desire to be the ones that bring the various kinds of students to be existed in good way in life, should be helped by students. It is because students have an important role in his position. Students should act as the person who brings great thought in his mind that must also bring changes that occur in their society. Communities are the ones who always read and viewed from different aspects that do a lot of things and source of problems that occur in our society. They are people who make a difference in many aspects of our lives. Teaching is an important task for us in bringing major changes to society and our teaching. By teaching, major changes will occur in the lives of our society. Teaching and learning process is one thing that is important and urgent for our nation and state. Lecturers have a full and important task for the community, and the nation. With qualified lecturers, nation enlightenment will be achieved.

Lecturer, in doing the teaching, will develop a plan for the implementation of the teaching and doing a lot of things in teaching and education. Teaching would require good teaching preparation. Good teaching requires good measuring tools to produce the desired results. In studying this measurement, it is needed a good tool like a team of professionals to work with and also a good measurement to quantity properly. In a society that appreciate the importance of this study well and independently. The result can obtained as follows. Evaluation of teamwork results obtained are:

\section{In accordance with Achieved SAP Learning Process}

This means that through the process of working with the existing team, the process will produce everything related to the unit of reference well and correctly. Working unit here is regarded as a working unit that has been agreed by all and also worked in agreed standards to achieve excellence and the process of the studies can be done well. It is expected to bring the result to the students who bring to other people who do a lot of things. The learning process will be achieved by a variety of things that led to changes in society.

2. Control

By doing the teamwork, everything will be handled by the team. The teamwork is a team that should do well. They must do everything with the control exercised by the control of various aspects, and they should be done well. This means that all parties must be well controlled by other faculty team. Mutual evacuation is a good thing to do in a society that upholds rule in teaching properly. This means that the teaching is done by the team can be controlled by all members.

\section{CONCLUSION}

The conclusion of this article is to conclude that team teaching performs better teaching. Through the team teaching, there will be a good control for teaching, so that teaching can be run well, compared with the individual teaching. Team Teaching will give more control and it will be better. By individual teaching, something that naturally occurs will also be different that the sense of power that lead to a better control of the students. Although sometimes happens to professors who are master in teaching, team teaching is Certainly better and it can lead to better teaching. The results of this study can provide recommendations for the teaching model is better between the models used individually or as a team to lead the teaching more striking at targets.

\section{ACKNOWLEDGMENT}

High appreciation to the Department of Anthropology, Universitas Padjadjaran. The author can get a lot of data in teaching to make this article for teaching in the Department of Anthropology, Universitas Padjadjaran.

\section{REFERENCES}

[1] Schroeder T \& Caplan B. On the Content of Experience. Philosophy and Phenomenological Research, 2006 November; 75(3): 591-93. Published by: International Phenomenological Society. [ Stable URL: http://www.jstor.org/stable/40041130]

[2] Haghighi JK \&, Abdollahi K. On the Efficacy of Team Teaching and Station Teaching in the Enhancement of Students' Reading Comprehension in an EAP Situation. Procedia - Social and Behavioral Sciences 2014 May 6; Vol 98: 887 p.

[3] Carless DR. Good practices in team teaching in Japan, South Korea and Hong Kong. System 2006 September; 34 (3): 349 p.

[4] Ellis RA, Hughes J, Weyers M. \& Riding P. University teacher approaches to design and teaching and concepts of learning technologies. Teaching and Teacher Education 2009 January; 25(1):115 p.

[5] Anderson RS. \& Speck BW. "Oh what a difference a team makes": Why team teaching makes a difference. Teaching and Teacher Education 1998 October; 14(7):674 p.

[6] Ulrich C \& Nedelcu A. Team-Teaching and Team Work: Perceptions Amongst Students and Staff (A Case Study). Procedia - Social and Behavioral Sciences, 2013 April 15; 76:856 p. 
[7] Savelsbergh ER, Prins GT, Rietbergen C, Fechner S, Vaessen BE, Draijer J, \& Bakker AM. Effects of Innovative Science and Mathematics Teaching on Student Attitudes and Achievement: A Meta-Analytic Study. Educational Research Review, In Press, Accepted Manuscript, Available online 26 July 2016. 14 p.

[8] Saine TP, The Evaluation of Teaching and the State of the University. The Modern Language Journal, Published by: Wiley on behalf of the National Federation of Modern Language Teachers Associations. 1979 November 63(7) 357 p. [Stable URL: http://www.jstor.org/stable/325983.]

[9] Fisher MO. Team Teaching in Houston. The English Journal 1962 December; 51(9) 629 p. Published by: National Council of Teachers of English. [Stable URL: http://www.jstor.org/stable/810254]

[10] Verble MS. Evaluating the Quality of Teaching. Peabody Journal of Education, Issues and Trends in American Education 1979 January; 56(2): 79 p. Published by: Taylor \& Francis, Ltd. [Stable URL: http://www.jstor.org/stable/1491878] 